\title{
Growth response of greenhouse-produced muskmelon and tomato to sub-surface drip irrigation and soil aeration management factors
}

Yuan $\mathrm{Li}^{1}$, Wenquan $\mathrm{Niu}^{2,3,4^{*}}$, Xiaoshu Cao ${ }^{1}$, Mingzhi Zhang ${ }^{1,5,6}$, Jingwei Wang ${ }^{2,7}$ and Zhenxing Zhang ${ }^{8,9}$

\begin{abstract}
Background: Hypoxia causes injury and yield loss. Soil aeration has been reported to accelerate the growth of plants and increase crop yield. The aim of this study was to examine growth response of greenhouse-produced muskmelon to 3 levels of sub-surface drip irrigation (I), 3 different installation depths of drip laterals in the soil (D), and 4 levels of supplemental soil aeration frequency (A). A fractional factorial experiment was designed to examine these treatment effects on marketable fresh fruit yield, leaf area index during 3 growth stages, and dry matter partitioning at harvest. In addition, we studied the response of fruit yield and dry matter of tomato to 2 levels of burial depths of subsurface tubing in combination with 3 frequency levels of soil aeration.
\end{abstract}

Results: Results showed that soil aeration can positively influence the yield, leaf area index, dry matter and irrigation use efficiency of the muskmelon $(p<0.05)$. The fruit yield of muskmelon and tomato were increased by 21.5 and $30.8 \%$ respectively with $1-d$ and $2-d$ aeration intervals compared with the no aeration treatment.

Conclusions: The results suggest that soil aeration can positively impact the plant root zone environment and more benefits can be obtained with aeration for both muskmelon and tomato plants.

Keywords: Supplemental soil aeration, Leaf area index, Dry matter partitioning, Muskmelon, Tomato

\section{Background}

Use of sub-surface drip irrigation under protective structures to produce high-value vegetables for the fresh food market is increasing in the semi-arid areas of Northwest China. These production technologies significantly improve water use efficiency compared to traditional spray or furrow irrigation systems [1-3]. The topsoil water content depends on the sub-surface drip application frequency, rate, depths, leakage and evapotranspiration.

\footnotetext{
* Correspondence: nwq@vip.sina.com

${ }^{2}$ Institute of Soil and Water Conservation, Northwest A\&F University, Yangling 712100, Shaanxi, China

${ }^{3}$ Institute of Water-saving Agriculture in Arid Areas of China (IWSA),

Northwest A\&F University, Yangling 712100, Shaanxi, China

Full list of author information is available at the end of the article
}

Manufacturer can vary the sub-surface depth of the buried drip tubing to facilitate cultivation along with the rate, amount, and frequency of irrigation to control the wetted portion of the root zone and optimize soil water availability and accessibility to the plant root system [4-6].

In addition to soil water, rhizosphere $\mathrm{O}_{2}$ content is one of the most important factor affecting respire, grow, develop, and function normally of plant roots $[5,7]$. Most of $\mathrm{O}_{2}$ supply is obtained directly by continuous diffusive air exchange between the atmosphere and soil [8]. Previous studies have shown that hypoxia stress limited leaf growth, the rate of leaf expansion declined, and the size of leaf reduced [9]. High $\mathrm{CO}_{2}$ concentrations (at $\left.2500 \mu \mathrm{L} \mathrm{L}^{-1}\right)$ or low (10\% by volume) $\mathrm{O}_{2}$ in the root- 
zone significantly increased the activity of lactate dehydrogenase (LDH), alcohol dehydrogenase (ADH), and pyruvate decarboxylase (PDC) in muskmelon plants, resulting in inhibition of growth, and decrease in fruit yield and quality [10-12].

Subsurface drip irrigation allows the application of air and soluble materials (such as $\mathrm{O}_{2}$, nutrients, pesticide) directly to the root zone. Studies have shown that these practices can be very useful in overcoming problems associated with hypoxia in the root zone of irrigated crops over a range of crops, soil water contents and soil types, and for improving crop performance under oxygendeficient conditions [13-15]. Aerated irrigation positively affected yield and improved quality for cotton, beans, squash, pumpkin, cucumber, tomato, rice and other crops especially on heavy and saline soils [16-20].

These demonstrated positive effects of aerated irrigation and supplemental aeration on growth and yield have not been completely explained in the literature. It is quite possible that improved LAI of the leaves may be a key mechanism for the increased yield and quality. For given ambient conditions (light, temperature, water, nutrition) crop growth and yield is directly related to LAI. Higher LAI, photosynthetic rate and chlorophyll content are key indicators and predictors of higher crop yields [21]. However, it is not known how changing sub-surface irrigation practices (tubing placement depth, irrigation level and frequency) and artificial aeration frequency would affect LAI.

We suspect that varying the aeration frequency, aeration volume, aeration position and irrigation amount would result in a possible change in rhizosphere soil environment, LAI, and irrigation use efficiency of plants, thus changing the plant growth and fruit output. The specific objective of this study was to determine the response of greenhouseproduced muskmelon and tomato plants on clay loam soils of the semi-arid area of Northwest China under various combinations of sub-surface irrigation volumes, tubing placement depth, and supplemental aeration frequency. Fresh fruit yield, leaf area index, and dry matter partitioning were taken as measures of response to these treatment factors.

\section{Results}

\section{Muskmelon results}

LAl of muskmelon

Values in the $\mathrm{LAI}_{25}$ row of Table 1 corresponded to the tendril elongation growth period. The $55 \mathrm{DAT}\left(\mathrm{LAI}_{55}\right)$ and $75 \mathrm{DAT}\left(\mathrm{LAI}_{75}\right)$ measurements were taken during the flowering and at fruit harvest. The overall mean of

Table 1 Marginal means and 2-factor interactions for marketable fruit yield, LAl, post-harvest dry matter partitioning, and irrigation use efficiency response of greenhouse-produced muskmelon plants to sub-surface drip-irrigation tubing placement depth $x$ soil aeration frequency $\mathrm{x}$ irrigation level treatment factors. In each row, the means for the levels of a given factor not followed by the same letter are significantly different at the $5 \%$ level. Two-factor interaction is significant at the $1 \%\left({ }^{*}\right)$, 5\% (*), or not significant (ns) level

\begin{tabular}{|c|c|c|c|c|c|c|c|c|c|c|c|c|c|c|c|c|}
\hline \multirow[t]{2}{*}{ Response } & \multicolumn{3}{|c|}{$\begin{array}{l}\text { Tubing Placement Depth } \\
(\mathrm{D} \mathrm{cm})\end{array}$} & \multicolumn{4}{|c|}{$\begin{array}{l}\text { Soil Aeration Frequency } \\
\left.\text { ( } \mathrm{A}_{\text {interval in day }}\right)\end{array}$} & \multicolumn{3}{|c|}{$\begin{array}{l}\text { Irrigation Level } \\
(\mathrm{I} \text { to \% field capacity })\end{array}$} & \multicolumn{6}{|l|}{ F-value } \\
\hline & $\mathrm{D}_{10}$ & $\mathrm{D}_{25}$ & $\mathrm{D}_{40}$ & $A_{1}$ & $\mathrm{~A}_{2}$ & $\mathrm{~A}_{4}$ & $A_{N}$ & $\mathrm{I}_{70}$ & $I_{80}$ & $I_{90}$ & D & A & 1 & DxA & Dxl & $\mathrm{Axl}$ \\
\hline Yield (kg) & $1.48 \mathrm{ab}$ & $1.59 a$ & $1.38 b$ & $1.64 a$ & $1.51 \mathrm{ab}$ & $1.43 b$ & $1.35 b$ & $1.53 a$ & $1.51 a$ & $1.40 \mathrm{a}$ & $\begin{array}{l}3.012 \\
\mathrm{~ns}\end{array}$ & $\begin{array}{l}1.995 \\
\mathrm{~ns}\end{array}$ & 0.753 ns & $\begin{array}{l}0.296 \\
\mathrm{~ns}\end{array}$ & $3.606^{*}$ & $\begin{array}{l}0.988 \\
\mathrm{~ns}\end{array}$ \\
\hline $\mathrm{LAl}_{25}$ & $1.41 \mathrm{a}$ & $1.41 \mathrm{a}$ & $1.11 \mathrm{a}$ & $1.63 a$ & $1.42 \mathrm{a}$ & 1.33a & $0.84 b$ & $1.38 a$ & $1.41 \mathrm{a}$ & $1.13 a$ & $\begin{array}{l}1.128 \\
\mathrm{~ns}\end{array}$ & $8.087^{* *}$ & $1.608 \mathrm{~ns}$ & $3.018^{*}$ & $\begin{array}{l}1.143 \\
\mathrm{~ns}\end{array}$ & $\begin{array}{l}2.674 \\
\text { ns }\end{array}$ \\
\hline $\mathrm{LAl}_{55}$ & $2.22 \mathrm{~b}$ & $3.05 a$ & $2.81 a$ & $3.11 \mathrm{a}$ & $2.55 a$ & $2.62 \mathrm{a}$ & $2.48 a$ & $2.52 \mathrm{a}$ & 2.61a & $2.94 a$ & $5.334^{* *}$ & $\begin{array}{l}1.028 \\
\mathrm{~ns}\end{array}$ & $2.029 \mathrm{~ns}$ & $\begin{array}{l}1.486 \\
\mathrm{~ns}\end{array}$ & $\begin{array}{l}1.792 \\
\mathrm{~ns}\end{array}$ & $\begin{array}{l}1.623 \\
\mathrm{~ns}\end{array}$ \\
\hline $\mathrm{LAl}_{75}$ & $2.31 b$ & $3.25 a$ & $3.02 \mathrm{a}$ & $3.00 a$ & $3.06 a$ & $2.96 a$ & $2.43 a$ & $2.63 a$ & $3.02 \mathrm{a}$ & $2.94 a$ & $5.788^{* *}$ & $\begin{array}{l}1.201 \\
\mathrm{~ns}\end{array}$ & 0.777 ns & $\begin{array}{l}1.017 \\
\mathrm{~ns}\end{array}$ & $\begin{array}{l}0.986 \\
\text { ns }\end{array}$ & $2.703^{*}$ \\
\hline Total DM (g) & $43.3 b$ & 52.9ab & $60.3 a$ & $62.6 a$ & $54.2 \mathrm{ab}$ & $49.2 b$ & $42.6 b$ & $52.2 \mathrm{a}$ & $51.6 a$ & $52.6 a$ & $5.347^{* *}$ & $3.900 *$ & 0.017 ns & $\begin{array}{l}0.440 \\
\text { ns }\end{array}$ & $3.821^{*}$ & $2.659^{*}$ \\
\hline Stem DM (g) & $11.3 b$ & $11.1 \mathrm{~b}$ & $13.2 \mathrm{a}$ & 13.6a & $12.2 \mathrm{ab}$ & $11.4 b c$ & $10.3 c$ & 12.1a & $11.9 a$ & $11.6 a$ & $4.325^{*}$ & $5.880^{* *}$ & $0.158 \mathrm{~ns}$ & $\begin{array}{l}2.450 \\
\mathrm{~ns}\end{array}$ & $7.550^{* *}$ & $5.376^{* *}$ \\
\hline Leaf DM(g) & $29.9 b$ & $40.1 \mathrm{a}$ & $44.9 a$ & $46.4 a$ & 39.9ab & 36.0ab & $30.9 b$ & $37.8 a$ & $37.9 a$ & $39.2 a$ & $5.109^{*}$ & $\begin{array}{l}2.589 \\
\text { ns }\end{array}$ & $0.041 \mathrm{~ns}$ & $\begin{array}{l}0.294 \\
\mathrm{~ns}\end{array}$ & $\begin{array}{l}2.469 \\
\mathrm{~ns}\end{array}$ & $\begin{array}{l}2.062 \\
\text { ns }\end{array}$ \\
\hline Root DM (g) & $2.01 a$ & $1.79 a$ & $2.14 a$ & $2.52 a$ & $2.07 \mathrm{~b}$ & $1.88 \mathrm{bc}$ & $1.47 \mathrm{c}$ & $2.31 a$ & $1.82 \mathrm{~b}$ & $1.82 \mathrm{~b}$ & $\begin{array}{l}1.187 \\
\mathrm{~ns}\end{array}$ & $8.887^{* *}$ & $3.337^{*}$ & $4.014^{* *}$ & $8.847^{* *}$ & $\begin{array}{l}2.320 \\
\text { ns }\end{array}$ \\
\hline $\operatorname{IUE}_{\mathrm{f}}\left(\mathrm{g}\right.$ liter $\left.^{-1}\right)$ & 17.0a & $18.8 \mathrm{a}$ & $15.8 \mathrm{a}$ & $20.0 a$ & $17.4 a$ & $15.1 \mathrm{a}$ & $16.3 a$ & $21.5 a$ & $17.2 \mathrm{~b}$ & $12.9 \mathrm{c}$ & $\begin{array}{l}0.986 \\
\text { ns }\end{array}$ & $\begin{array}{l}1.450 \\
\mathrm{~ns}\end{array}$ & $14.198^{* *}$ & $\begin{array}{l}1.623 \\
\mathrm{~ns}\end{array}$ & $\begin{array}{l}2.677 \\
\text { ns }\end{array}$ & $6.178^{* *}$ \\
\hline$I_{U} E_{d m}\left(g\right.$ liter $\left.^{-1}\right)$ & $6.15 b$ & 7.64ab & $8.94 a$ & $9.75 a$ & $7.81 \mathrm{ab}$ & $6.53 b$ & $6.20 \mathrm{~b}$ & $9.23 a$ & $7.29 b$ & $6.20 \mathrm{~b}$ & $\begin{array}{l}2.827 \\
\mathrm{~ns}\end{array}$ & $2.971^{*}$ & $3.524^{*}$ & $4.388^{* *}$ & $5.694^{* *}$ & $3.996^{* *}$ \\
\hline
\end{tabular}

Yield is kg per plant for all marketable fruits harvested at 75 day after transplanting (DAT); LAI = Leaf area index measured by canopy solar radiation transmittance method; $L A I_{x x} L A I$ measured at xx DAT; DM g per plant dry matter at $75 D A T$; $I U E_{f}$ or $I U E_{d m}$ irrigation use efficiency as (marketable fresh fruit yield per plant) or as ( $g$ total DM per plant) divided by (liter total irrigation water applied) 
2.69 at 40 DAT was close to double the value of 1.31 at 25 DAT. At 75 DAT the LAI of 2.86 was only about $4 \%$ higher than at 40 DAT. The $10 \mathrm{~cm}$ tubing placement depth tended to be significantly lower compared to 25 and $40 \mathrm{~cm}$ depth for the 55 and 75 DAT measurements. Differences between the LAI marginal means for irrigation level were non-significant for all 3 sampling dates (Table 1). Among the single-factor analyses, tubing placement depth had a significant impact on both $\mathrm{LAI}_{55}$ and $\mathrm{LAI}_{75}$, aeration frequency had an extremely significant impact on $\mathrm{LAI}_{25}$. The identified significant $\mathrm{D} \times \mathrm{A}$ interaction for $\mathrm{LAI}_{25}$, and $\mathrm{A} \times \mathrm{I}$ interaction for LAI during the tendril elongation growth period and fruit harvest period.

The 1-way ANOVA showed that $\mathrm{LAI}_{25}$ values were all $<2.00$ for all treatment combinations (Fig. 1). The highest $\mathrm{LAI}_{25}$ value of 1.87 for the $\mathrm{D}_{10} \mathrm{~A}_{1} \mathrm{I}_{80}$ treatment combination was significantly higher $(\mathrm{P}<0.01)$ than all the non-aerated combinations with values $<1.00$ (namely $\left.\mathrm{D}_{10} \mathrm{~A}_{\mathrm{N}} \mathrm{I}_{70}=0.81, \quad \mathrm{D}_{25} \mathrm{~A}_{\mathrm{N}} \mathrm{I}_{80}=0.85, \quad \mathrm{D}_{40} \mathrm{~A}_{\mathrm{N}} \mathrm{I}_{90}=0.85\right) \quad$ regardless of depth and irrigation level. Treatment combinations with daily soil aeration tended to be higher or similar to those with the 2-day and 4-day soil aeration frequency. Combination with $\mathrm{D}_{40}$ and $\mathrm{A}_{4}$ gave $\mathrm{LAI}_{25}<1$. Combinations with higher $\mathrm{A}_{2}$ and $\mathrm{A}_{1}$ aeration frequency and shallower $D_{25}$ and $D_{10}$ placement depth gave $\mathrm{LAI}_{25}>1$ indicating that lowering placement depth could offset the negative impact of lowering soil aeration frequency (Fig. 1).

The highest $\mathrm{LAI}_{55}$ value of 3.60 during the flowering period was obtained for the $\mathrm{D}_{25} \mathrm{~A}_{1} \mathrm{I}_{90}$. $\mathrm{LAI}_{55}$ values > 3.00 were obtained only for the $\mathrm{D}_{25} \mathrm{~A}_{4} \mathrm{I}_{80}(=3.22)$ and $\mathrm{D}_{40} \mathrm{~A}_{1} \mathrm{I}_{70}(=3.32)$ treatment combinations. These $\mathrm{LAI}_{75}$ values for these combinations were practically the same as those for $\mathrm{LAI}_{55}$. It would appear that 3.00 to 3.60 may represent the maximum LAI range for the Shantian No. 1 muskmelon cultivar as measured under the experimental conditions.

Except for the $\mathrm{D}_{10} \mathrm{~A}_{\mathrm{N}} \mathrm{I}_{70}$ treatment combination with $\mathrm{LAI}_{55}=1.87$, all the 8 remaining combination $\mathrm{LAI}_{55}$ values were between 2.00 and 3.00. For the $\mathrm{D}_{25} \mathrm{~A}_{1} \mathrm{I}_{90}$ combination, the $\mathrm{LAI}_{55}=3.60$ represented a $116 \%$ increase on the $\mathrm{LAI}_{25}=1.66$ value. Corresponding increases were 112 and $154 \%$ for the $\mathrm{D}_{25} \mathrm{~A}_{4} \mathrm{I}_{80}$ and

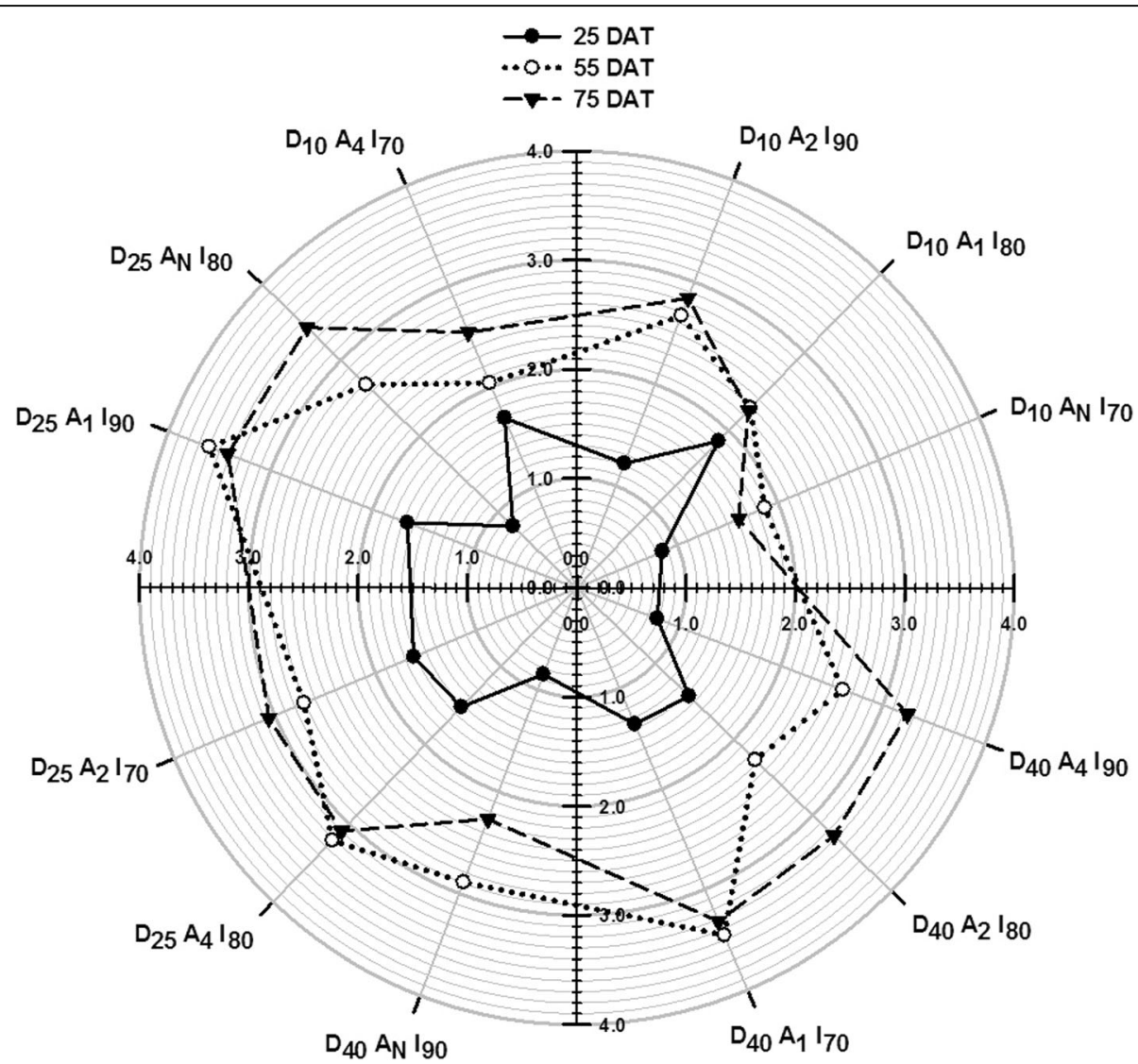

Fig. 1 LAl of muskmelon plants measured by canopy solar radiation transmittance at 25, 55, and 75 days after transplanting for each combination of drip-tubing placement depth, soil aeration frequency, and irrigation level treatment factors. Combination treatment means are annotated along polar axis. Ducan 0.05 for mean comparison at 25, 55, and 75 DAT were 0.50, 1.16, and 1.12 
$\mathrm{D}_{40} \mathrm{~A}_{1} \mathrm{I}_{70}$ treatment combinations. Increases for $\mathrm{LAI}_{55}$ relative to $\mathrm{LAI}_{25}$ tended to be higher for combinations with the lower $\left(\mathrm{A}_{4}\right.$ and $\left.\mathrm{A}_{\mathrm{N}}\right)$ soil aeration frequency and especially for the higher irrigation levels $\left(I_{90}\right)$ (Table 1 ). As indicated the $\mathrm{LAI}_{75}$ values were very close to the $\mathrm{LAI}_{55}$ for some combinations indicating little leaf growth after the flowering and during the fruit enlargement growth stages. $\mathrm{LAI}_{75}$ values were markedly lower than $\mathrm{LAI}_{55}$ for the $\mathrm{D}_{10} \mathrm{~A}_{\mathrm{N}} \mathrm{I}_{70}$ and $\mathrm{D}_{40} \mathrm{~A}_{\mathrm{N}} \mathrm{I}_{90}$ treatment combinations indicating possible earlier senescence.

\section{Dry matter partitioning and irrigation use efficiency of muskmelon}

Total dry matter of muskmelon progressively increased with increasing tubing placement depth and progressively decreased with decreasing soil aeration frequency (Table 1). Decreased soil aeration frequency tended to progressively reduce all 3 components of the total DM. The effects were more marked for the leaf and root contributions. The marginal mean for leaf and root DM with daily soil aeration was 50 and $71 \%$ higher than the values for no aeration. The corresponding value for stem DM was 32\%. The marginal mean for root DM was significantly higher for the $\mathrm{I}_{70}$ irrigation level compared to the $I_{80}$ and $I_{90}$ levels. In addition, interaction analysis found that D x A and D x I significantly affected the root
DM, D x I and A x I significantly affected the Total DM and Stem DM. Overall mean total DM was $52.2 \mathrm{~g}$ per plant partitioned as $11.9 \mathrm{~g}$ in stem $+38.3 \mathrm{~g}$ in leaf $+2.0 \mathrm{~g}$ in root representing 22.7, 73.4, and $3.9 \%$ respectively. These DM partitioning percentages were similar for each of the tubing placement depths, soil aeration frequencies, and irrigation levels. Values ranged between 21 and $26 \%, 68-75 \%$, and $3-4 \%$ respectively for the stem, leaf, and root contribution to the total DM for all levels of the treatment factors (Table 1). The $\mathrm{D}_{40} \mathrm{~A}_{1} \mathrm{I}_{70}$ treatment combination resulted in the maximum plant root, stem, leaf and total DM values (Fig. 2). As shown, the plant root, stem, leaf and total DM values for treatment combinations with daily soil aeration tended to be higher than those with the no aeration.

The ternary plot (Fig. 3) show the range of the ratios for root, stem, and leaf DM of muskmelon to total postharvest DM at 75 days after transplanting for each treatment combination. The root DM percentages fell between 2.8 to $5.4 \%$. The leaf DM range was 67.5 to $75.7 \%$ and 20.6 to $28.5 \%$ for the stem DM. These ranges were quite narrow indicating that the treatment combinations did not markedly affect DM partitioning in the muskmelon plants. Nevertheless, it would be interesting to examine the clusters of treatment combinations at the high and low ends of these ranges as shown in Fig. 3.

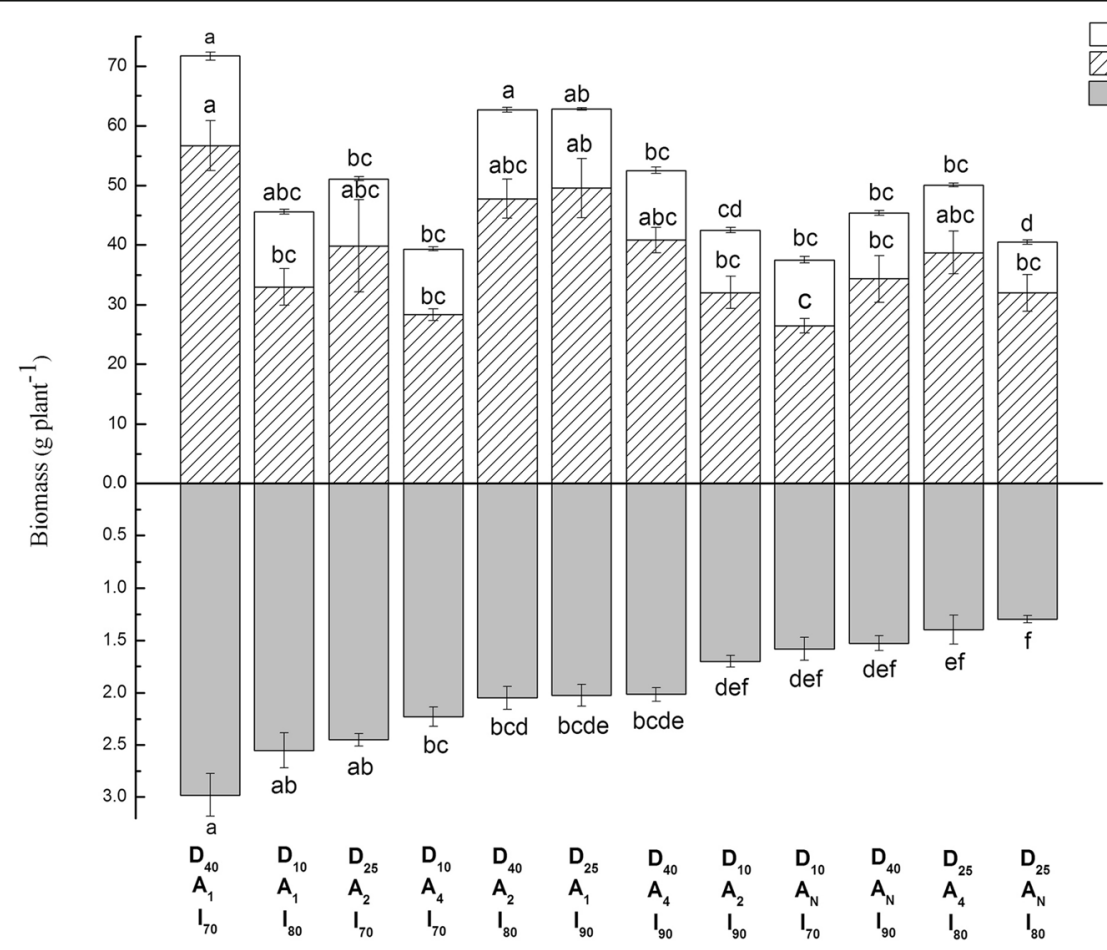

Fig. 2 Post-harvest stem, leaf, and root dry matter of muskmelon plants measured at 75 days after transplanting for each combination of driptubing placement depth, soil aeration frequency, and irrigation level treatment factors. Bars on the stacked sections for each component represent the standard error of the mean. Means not followed by the same letter are significantly different at the $5 \%$ level 


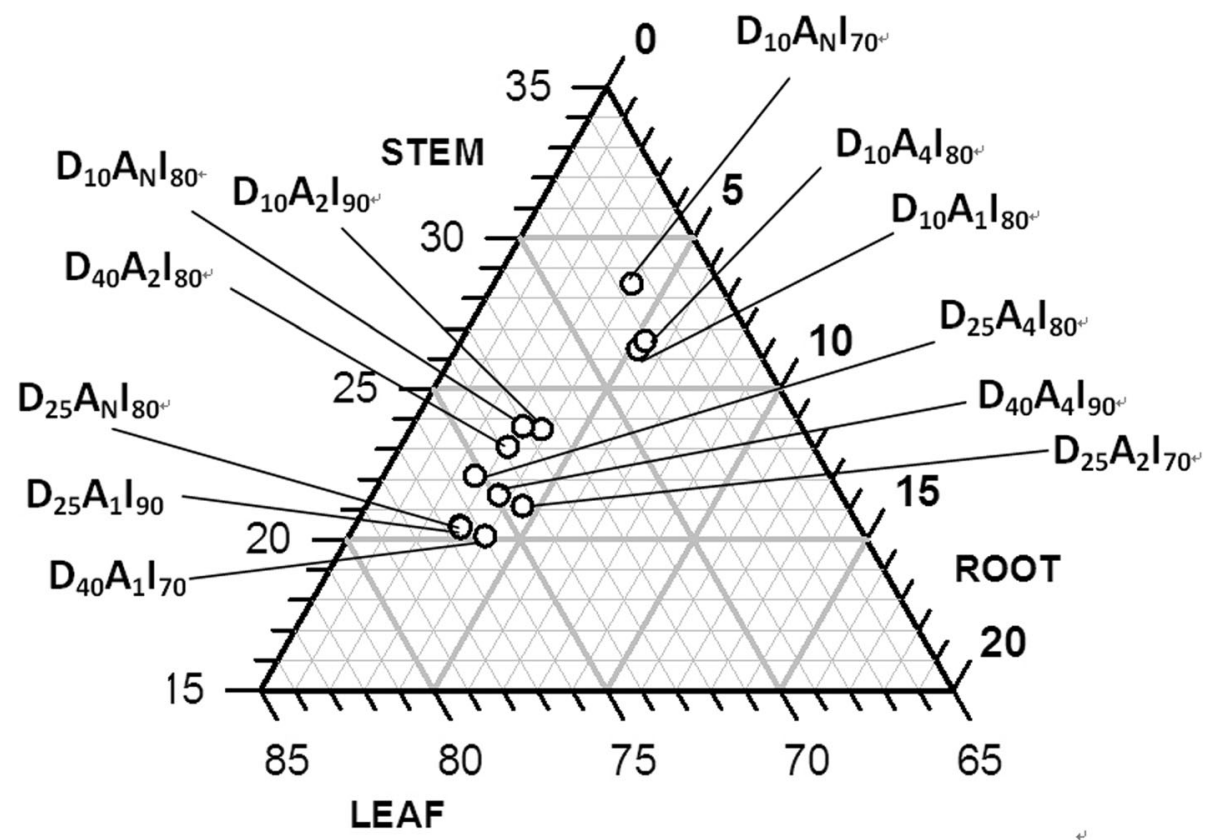

Fig. 3 Ternary plot of root, stem, and leaf dry weight of muskmelon expressed as \% of total post-harvest plant dry weight measured at 75 days after transplanting foreach combination of drip tubing placement depth, soil aeration frequency, and irrigation level treatment factors

The cluster with high stem DM percentages was $\mathrm{D}_{10} \mathrm{~A}_{\mathrm{N}} \mathrm{I}_{70}>\mathrm{D}_{10} \mathrm{~A}_{4} \mathrm{I}_{80}>\mathrm{D}_{10} \mathrm{~A}_{1} \mathrm{I}_{80}$ treatment combinations (Fig. 3). The treatment cluster of low leaf DM percentages was $\mathrm{D}_{10} \mathrm{~A}_{\mathrm{N}} \mathrm{I}_{70}<\mathrm{D}_{10} \mathrm{~A}_{4} \mathrm{I}_{80}<\mathrm{D}_{10} \mathrm{~A}_{1} \mathrm{I}_{80}$ compared with the cluster of high leaf DM percentages $D_{25} A_{N} I_{80}>$ $\mathrm{D}_{25} \mathrm{~A}_{1} \mathrm{I}_{90}>\mathrm{D}_{40} \mathrm{~A}_{1} \mathrm{I}_{70}$ treatment combinations. High root DM percentages was obtained for the $\mathrm{D}_{10} \mathrm{~A}_{4} \mathrm{I}_{80}>$ $\mathrm{D}_{10} \mathrm{~A}_{1} \mathrm{I}_{80}$ cluster of treatment combinations. These clusters tended to confirm the existence of 2-factor interactions (Table 1).

The overall irrigation use efficiency for marketable fruit yield of muskmelon $\left(\mathrm{IUE}_{\mathrm{f}}\right)$ across each treatment factor in Table 1 was $17.2 \mathrm{~g}$ per plant per liter of total irrigation water applied (subsurface drip + initial $70 \mathrm{~mm}$ surface irrigation immediately at prior to transplanting). Neither tubing placement depth nor soil aeration resulted in significant differences in the $\mathrm{IUE}_{\mathrm{f}}$ marginal means. The $\mathrm{IUE}_{\mathrm{f}}$ marginal mean was $21.5 \mathrm{~g}$ fresh fruit per plant per liter for the $\mathrm{I}_{70}$ irrigation level. Corresponding values decreased linearly by 20 and $40 \%$ for $\mathrm{I}_{80}$ $(=17.2)$ and $I_{90}(=12.9)$. These decreases were significantly $(p<0.05)$ different. The 3-way ANOVA indicated a highly significant 2 -factor $A \times$ I interaction effect (Table 1).

The overall irrigation use efficiency $\left(\mathrm{IUE}_{\mathrm{dm}}\right)$ for total dry matter (stem + leaf + root) of muskmelon across each treatment factor in Table 1 was $7.58 \mathrm{~g}$ per plant per liter of total irrigation water applied. All treatment factors significantly affected $I_{U E}$ and all 2-factor interactions were highly significant (Table 1 ). The $\mathrm{IUE}_{\mathrm{dm}}$ value for $\mathrm{D}_{40}(=8.94)$ was significantly higher than for $\mathrm{D}_{10}(=$ 6.15 ) by $45 \%$. Similarly, $\mathrm{IUE}_{\mathrm{dm}}$ progressively increased with increasing aeration frequency from 6.20 for $A_{N}$ to 6.53, for $A_{4}$, to 7.81 for $A_{2}$, and 9.75 for $A_{1}$. The $57 \%$ increase between the values for $\mathrm{A}_{\mathrm{N}}$ and $\mathrm{A}_{1}$, and the $49 \%$ increase between $A_{4}$ and $A_{1}$, were significant $(P<0.05)$. $\mathrm{IUE}_{\mathrm{dm}}$ values decreased with increasing irrigation level. The marginal mean of 9.23 for $\mathrm{I}_{70}$ differed significantly from to the value of 7.29 for $\mathrm{I}_{80}$ (20\% lower), and 6.20 for $\mathrm{I}_{90}$ (33\% decrease).

\section{Marketable fresh fruit yield of muskmelon}

The results in Table 1 show significant treatment main effects for the drip tubing placement depth and soil aeration frequency experimental factors. Increasing depth of tubing tended to decrease the marketable fresh fruit yield per plant in a non-linear manner. Values increased non-significantly from 1.48 to $1.59 \mathrm{~kg}$ per plant between the $10 \mathrm{~cm}$ to $25 \mathrm{~cm}$ tubing placement depth. However, the mean of $1.38 \mathrm{~kg}$ per plant for the $40 \mathrm{~cm}$ placement depth was significantly lower than for the $25 \mathrm{~cm}$ depth (Table 1). Only the D x I two-factor interaction on fresh fruit yield was significant (Table 1) indicating that the tubing placement depth effect would be different for the various irrigation levels. This was due to tubing placement depth determine the position of the soil wetted. Uneven redistribution of soil water in different longitudinal position result in different water use efficiency and fruit yield. It seems that the optimal installation depth of drip pipes is around $25 \mathrm{~cm}$. However, the fractional 
factorial design does not permit examination of the simple effects of placement depth at each irrigation level.

Yield progressively decreased with decreasing soil aeration frequency from $1.64 \mathrm{~kg} /$ plant with daily aeration to 1.51, 1.431 .35 with 2-day, 4- day, and no aeration, respectively (Table 1). A comparison of means showed that although the daily value was not significantly better the 2-day frequency, it was significantly better than the 4-day and no aeration treatment (Table 1). Irrigation means were not significantly different. Values were 1.53 $\mathrm{kg} /$ plant for irrigating to $70 \%$ of field capacity and 1.51 and $1.40 \mathrm{~kg} /$ plant for the 80 and $90 \%$ of field capacity levels (Table 1).

The one-way ANOVA for marketable yield supported the foregoing results. When arranged in descending order, the marketable yield in $\mathrm{kg}$ per plant tended to fall into several groups for the 12 treatment combinations (Fig. 4). A high-value group comprising in order $\mathrm{D}_{25} \mathrm{~A}_{2} \mathrm{I}_{70}$ (1.67 kg per plant) $>\mathrm{D}_{10} \mathrm{~A}_{1} \mathrm{I}_{80}(1.65)=\mathrm{D}_{40} \mathrm{~A}_{1} \mathrm{I}_{70}$ (1.65) $>\mathrm{D}_{25} \mathrm{~A}_{1} \mathrm{I}_{90}$ (1.63); an intermediate group $\mathrm{D}_{25} \mathrm{~A}_{4} \mathrm{I}_{80}$ (1.54) $>\mathrm{D}_{25} \mathrm{~A}_{\mathrm{N}} \mathrm{I}_{80} \quad(1.50)>\mathrm{D}_{10} \mathrm{~A}_{2} \mathrm{I}_{90}$ (1.48); a low yield group $\mathrm{D}_{10} \mathrm{~A}_{4} \mathrm{I}_{70} \quad(1.40)>\mathrm{D}_{10} \mathrm{~A}_{\mathrm{N}} \mathrm{I}_{70} \quad(1.38)>\mathrm{D}_{40} \mathrm{~A}_{2} \mathrm{I}_{80}$ (1.37) $>\mathrm{D}_{40} \mathrm{~A}_{4} \mathrm{I}_{90}$ (1.34). The lowest yield of $1.16 \mathrm{~kg}$ per plant was obtained for $D_{40} A_{N} I_{90}$. The high values group included all the high frequency $\left(\mathrm{A}_{1}\right)$ soil aeration. The lower frequency aeration $\left(\mathrm{A}_{2}, \mathrm{~A}_{4}, \mathrm{~A}_{\mathrm{N}}\right)$ and the higher irrigation level means $\left(I_{80}\right.$ and $\left.I_{90}\right)$ were associated with the low value group. These results tend to confirm a positive effect of soil aeration.

Given a measured 4 to 5 fruits per plant, the foregoing results imply increasing fruit size for the grouping of the treatment combinations. Average fresh fruit weight ranged from 232 to $290 \mathrm{~g}$ for the lowest yield of $1.16 \pm$ $0.08 \mathrm{~kg}$ for $\mathrm{D}_{40} \mathrm{~A}_{\mathrm{N}} \mathrm{I}_{90}$. The range for the low value group average of $1.37 \pm 0.20 \mathrm{~kg}$ was 275 to $343 \mathrm{~g}$, for the intermediate group with $1.41 \pm 0.29 \mathrm{~kg}$ was 300 to $376 \mathrm{~g}$, and for the high value group with $1.65 \pm 0.43 \mathrm{~kg}$ was 330 to $412 \mathrm{~g}$. The overall mean across all treatment factors in Table 1 and treatment combinations was $1.48 \mathrm{~kg}$ per plant giving an overall average fresh fruit weight ranging between 300 to $360 \mathrm{~g}$ for the Shantian No. 1 cultivar.

\section{Tomato results}

\section{Dry matter partitioning of tomato}

Figure 5 shows that Post-harvest stem, leaf, and root dry matter of tomato was greater with aeration than without aeration treatment. For both tube burial depths, Postharvest stem, leaf, and root DM increased with increasing aeration frequency. Maximal values for stem, leaf, and root $\mathrm{DM}$ were obtained in the $\mathrm{D}_{15} \mathrm{~A}_{2}, \mathrm{D}_{40} \mathrm{~A}_{2}, \mathrm{D}_{40} \mathrm{~A}_{4}$ treatments, respectively. Our investigation found that root DM of tomato with a $40-\mathrm{cm}$ burial of the drip irrigation tube was higher than $15-\mathrm{cm}$ treatment. The

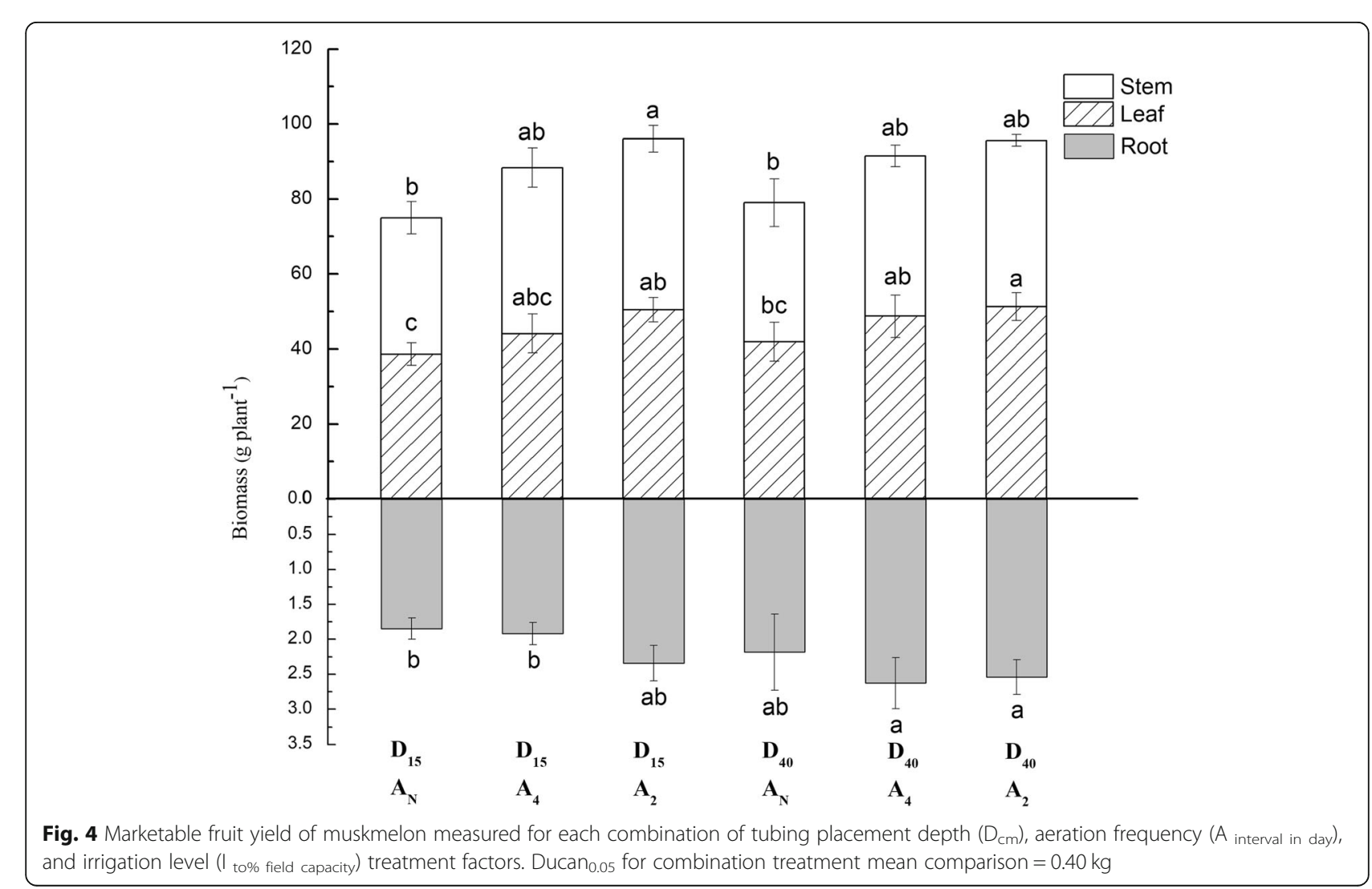




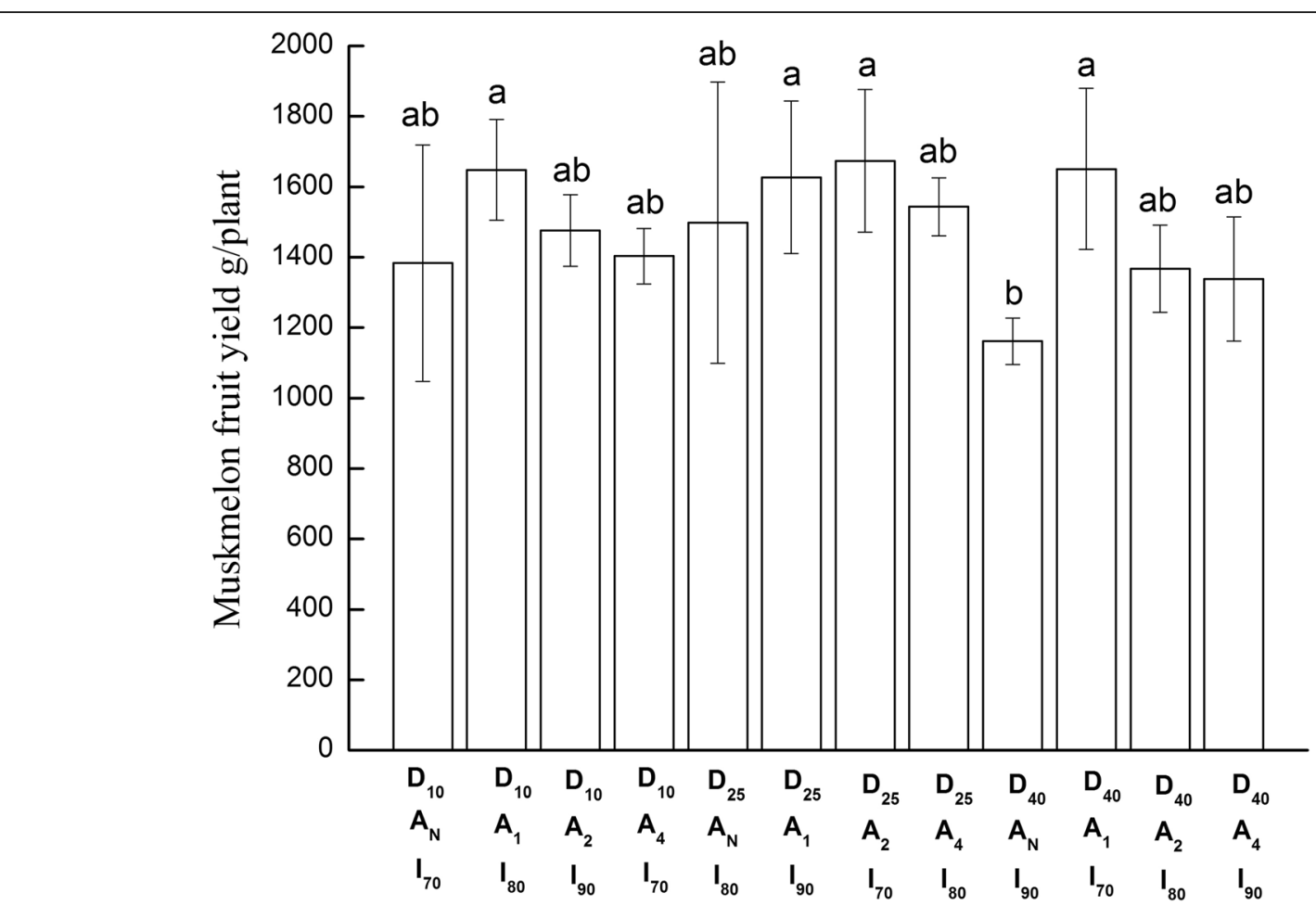

Fig. 5 Post-harvest stem, leaf, and root dry matter of tomato measured for each combination of tubing placement depth $\left(D_{\mathrm{cm}}\right)$ and aeration frequency $\left(A_{\text {interval in day }}\right.$ ) treatment factors. The differences were compared using the Duncan's test with a significance level of 0.05

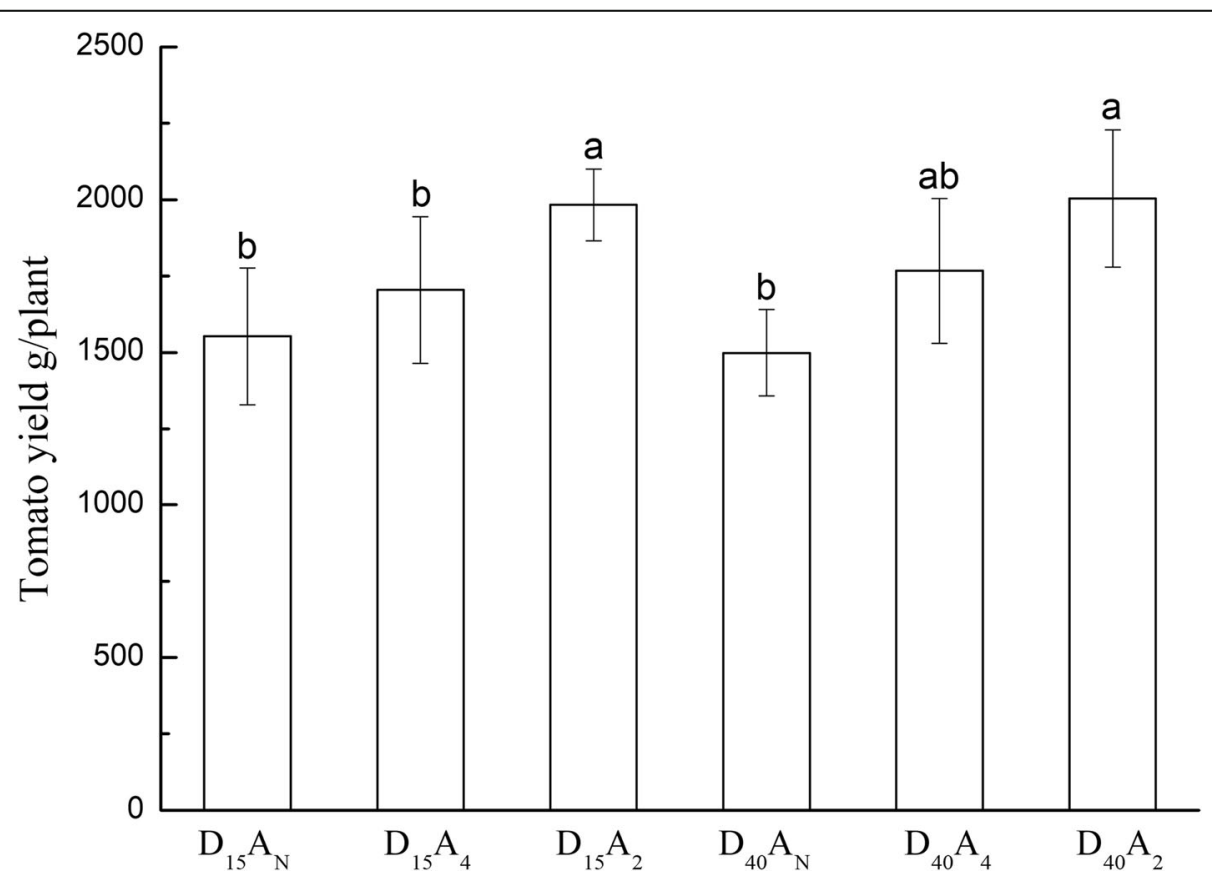

Fig. 6 Fruit yield of tomato for each combination of tubing placement depth $\left(D_{c m}\right)$ and aeration frequency $\left(A_{\text {interval in day }}\right)$ treatment factors. The differences were compared using the Duncan's test with a significance level of 0.05 
highest Total dry matter (stem + leaf + root DM) value of $98.4 \mathrm{~g}$ was obtained for the $\mathrm{D}_{15} \mathrm{~A}_{2}$.

\section{Marketable fresh fruit yield of tomato}

Soil aeration improved plant root growth environment, thus increasing yield. Fig. 6 shows that the tomato yield was significantly different between aeration treatments. The results are found for the yield as aeration treatments had significantly higher yield than CK. The $\mathrm{D}_{15} \mathrm{~A}_{2}$ treatment combination resulted in the maximum tomato yield (Fig. 6). The $D_{15} A_{2}$ was increased the tomato yield by $27.8 \%$ compared with the $D_{10} A_{N}$.

\section{Discussion}

Sub-surface drip irrigated systems are managed to optimize soil water availability, accessibility, and use efficiency for maximum growth and marketable yield. On the other hand, irrigation always results in displacement and/or redistribution of soil air. This can reduce the level and availability of $\mathrm{O}_{2}$ which is continuously needed to act as the electron acceptor in the tricarboxylic acid metabolic cycle, ATP production, and normal root cell activity [22, 23]. Oxygen-deprivation destroys mitochondria and proteins in root cells leading to cytoplasm acidosis and plant growth inhibition [24]. In this context, it would be expected that any negative growth impact of increasing irrigation application can be offset by soil aeration delivered via the drip-irrigation tubing when placed at a given depth in the soil.

\section{Effect of soil aeration on muskmelon and tomato growth} Hypoxia induces a shift from normal respiration to anaerobic respiration. Previous studies have shown that artificial aeration significantly improved dry matter accumulation, yield, and water use efficiency of muskmelon cotton, wheat, tomato and pineapple $[5,25,26]$. Our results showed that soil aeration had a positive effect on both muskmelon and tomato plant growth. Both muskmelon and tomato DM increased with increasing aeration frequency indicating that rhizospheric oxygen stress do exist, and soil aeration would more likely ameliorate hypoxic conditions.

Applying $405 \mathrm{~L}$ of air through the average of 36 emitters would imply soil ventilation at a rate of about $11 \mathrm{~L}$ per emitter. It would be expected that most of this air would move upwards by convection displacing existing gases in the air-filled porosity above the plane of the drip lines. In short, the aeration treatments would in effect flush this air-filled porosity. This flushing effect would impact a larger volume of soil with increasing tubing placement depth. Permanent or semi-permanent subsurface drip irrigation systems need to be placed at depths that permit mechanical surface cultivation. This would reduce the potential of hypoxia. The air-filled porosity in a given soil volume would increase as water is removed by evapo-transpiration. More frequent flushing would increase $\mathrm{O}_{2}$ available for root metabolic activities and promote root growth.

Increasing levels of aeration frequency would supply more $\mathrm{O}_{2}$ for plant aerobic respiration and generally this would positively increase growth and yield. Any positive effect of aeration increasing soil ventilation on root growth would translate into improved yield and growth as reflected in the consistently higher values of yield, LAI, and DM with increasing soil aeration frequency. Aeration frequency significantly increased tomato growth performance and fruit yield (Table 1). As expected, increasing aeration frequency progressively increased dry matter and marketable fresh fruit yield of tomato (Fig. 5, Fig. 6). This study indicate that soil aeration can significantly increase the plant growth performance. It is consistent with previous studies of tomato, pepper and potato [27-30]. In addition, the aeration treatments tended to significantly impact most responses measured after $25 \mathrm{DAT}$. Although soil aeration did not significantly affect the $\mathrm{LAI}_{55}$ and $\mathrm{LAI}_{75}$, the leaf DM response was significant. The reason for this is most likely due to uncontrollable factors (such as solar angle, cloudiness, etc.) that increase the variability in the measured LAI by the canopy solar radiation transmittance method.

\section{Effect of irrigation on muskmelon growth}

The plots were drip-irrigated at 23 and 60 DAT based on the measured gravimetric water content averaged over the $0-60 \mathrm{~cm}$ depth of the soil profile on these dates. Based on the volumetric water content of 0.24 measured at transplanting there would be an additional $100 \mathrm{~mm} \mathrm{x}$ $(0.24-0.13)=11 \mathrm{~mm}$ of plant available water in the 50 $60 \mathrm{~cm}$ profile depth. This would imply a total of $136 \mathrm{~mm}$ when added with the $125 \mathrm{~mm}$ made available in the 0 $50 \mathrm{~cm}$ from the surface irrigation at the time of transplanting. This stored water would support an evapotranspiration rate of close to $6 \mathrm{~mm}$ per day over the 0 23 DAT period. This implies there was very likely no soil water deficits during this period. Any effect of the deficit drip irrigation levels at the different tubing placement depths would therefore be more apparent for responses measured after 25 DAT.

At 23 and 60 DAT the plots were drip irrigated with a volume equivalent to the amount required to replenish the measured soil water storage in the $0-60 \mathrm{~cm}$ profile depth to 70,80 , or $90 \%$ of field capacity. For the $I_{70}$ treatment, this would imply making plant available water in the soil wetted volume around the emitters equal to $600 \times(0.7 \times 0.38-0.13) \mathrm{mm}=82 \mathrm{~mm}$ for both the 37-day period between 23 and $60 \mathrm{DAT}$, and for the 15-day period between 60 DAT and harvest at 75 DAT. 
Corresponding values were $104 \mathrm{~mm}$ for $\mathrm{I}_{80}$ and $127 \mathrm{~mm}$ for $\mathrm{I}_{90}$.

The physical and hydraulic properties of the deep, loess-derived clay loam soil used in this study were quite uniform with depth. Therefore, it would be expected that the shape and volume of the wetted soil around each emitter would be similar for all tubing placement depths. The shape and dimensions of the wetted soil around the buried emitters would be important in trying to explaining the growth responses to the subsurface drip irrigation treatments for different tubing placement depths (Table 1 and Figs. 1, 2, 3, 4).

In this study, the emitters were spaced $30 \mathrm{~cm}$ along the tubing and the tubing was placed $50 \mathrm{~cm}$ apart. The foregoing review indicates that the entire thickness of the soil profile for at most $13 \mathrm{~cm}$ above and $13 \mathrm{~cm}$ below the plane of the drip line placement depths would be wetted by drip irrigation. This thickness would increase with increasing irrigation level. These literature results relating to a soil with the same texture as that used in this study, along with the non-significant effects of irrigation level on most of the post-25 DAT responses (Table 1), tend to confirm that soil water was not a limiting factor in this experiment. The marketable fruit yield, $\mathrm{LAI}_{55}$, and $\mathrm{LAI}_{75}$ remained unaffected by irrigation level (Table 1, Figs. 1 and 2). For all the measured dry matter accumulation responses at $75 \mathrm{DAT}$, only the root DM means for the $I_{80}$ and $I_{90}$ irrigation levels were significantly lower compared to the $\mathrm{I}_{70}$ level mean (Table 1 and Fig. 2). The irrigation use efficiency for both fruit yield $\left(\mathrm{IUE}_{\mathrm{f}}\right)$ and total $\mathrm{DM}$ accumulation $\left(\mathrm{IUE}_{\mathrm{dm}}\right)$ decreased significantly with increasing irrigation level (Table 1). This would imply that irrigation water applied above the $I_{70}$ level did not contribute to growth and yield since there was no effect of irrigation level on fruit yield and total DM accumulation.

\section{Effect of burial depths of subsurface tubing on muskmelon and tomato growth}

Increasing the placement depth for a given irrigation/ aeration level would correspondingly change the position of the soil moisture or soil $\mathrm{O}_{2}$ around the emitter. The shape of the wetted volume is expected to change with depth also in homogenous soils due to the effects of transpiration, evaporation and/or ground water. In addition, in soils with marked changes in physical and hydraulic properties with depth increasing the emitter depth would also induce changes in the shape of the wetted volume. Both muskmelon and tomato are moderate-rooted plant, the roots are mainly distributed within $40 \mathrm{~cm}$ of the soil surface. The results showed that muskmelon plant DM increased with increasing tubing placement depth (Fig. 2, Table 1). We speculate that lower dry matter accumulation at a shallow depth (10-
$25 \mathrm{~cm}$ ) of aeration/ irrigation lines due to the chimney effect. For the root zone soil texture used in this study, the experimental results, in their entirety, tend to support this reasoning. In addition, Wetting the profile 13 $\mathrm{cm}$ above and $13 \mathrm{~cm}$ below the plane of the drip line placement would imply increasing potential water losses due to soil evaporation for the shallow placement depth with $\mathrm{D}_{10}>\mathrm{D}_{25}>\mathrm{D}_{40}$.

\section{Interactions of soil aeration, burial depths and irrigation on plant growth}

Tomato is a moderate rooted plant, the roots are mainly distributed within $40 \mathrm{~cm}$ of the soil surface. Until 23 DAT only the soil aeration treatments were applied via the 10,25 , and $40 \mathrm{~cm}$ tubing placement depths. Neither irrigation levels or tubing placement depth had any effect on the marginal mean for $\mathrm{LAI}_{25}$. Any effect of these 2 treatment factors would be apparent in the LAI measured at 25 DAT. Nevertheless, the 2-factor D x A interaction was significant affected $\mathrm{LAI}_{25}$ (Table 1 ). On the other hand, all the soil aeration treatments positively affected $\mathrm{LAI}_{25}$ compared to the no aeration treatment. This suggests that low natural soil aeration may be a limiting factor in the clay loam soil used in this study. It confirms that artificial ventilation would positively affect growth, and provides more support for studies showing beneficial effects of this practice as was reported by Bhattarai et al. [17] in his comprehensive review of soil aeration research. According to our studies we found that only the D x I two-factor interaction was significant affected muskmelon fruit yield (Table 1). This suggests that tubing placement depth determine the position of the soil wetted. The difference of rhizosphere soil moisture results in the plants grow differently. Soil aeration would more likely ameliorate hypoxic conditions above, rather than below, the emitter. If tubing is placed at a shallow depth $(10 \mathrm{~cm})$, plant growth and fruit yield might not be improved significantly because of the chimney effect (Table 1). Also, the 2-factor D x A interaction on $\mathrm{LAI}_{25}$ and Root DM were significant indicating that the aeration effect may not be independent of application depth in an initially wet soil profile. On the other hand, the significant 2 factor D x I and A x I interactions on $\mathrm{IUE}_{\mathrm{dm}}$ indicated that the irrigation level effects varied differently for the tubing placement and aeration treatment factors.

The foregoing discussion raises the question as to whether the roots were able to fully access all the plant available water. Also, how could soil aeration influence the IUE and dry matter partitioning? Unfortunately, there are no recent field investigations on the root system development of muskmelon plants and how the roots explore the soil profile. Assuming a similar overall root architecture and distribution for the Hami melon, it 
was quite possible that some of the total applied irrigation at the $\mathrm{I}_{80}$ and $\mathrm{I}_{90}$ may not have been accessible to the plants. If so, this would explain the lack of irrigation effect on the growth responses and the significant decreases in $\mathrm{IUE}_{\mathrm{f}}$ and $\mathrm{IUE}_{\mathrm{dm}}$ with increasing irrigation level (Table 1, Figs. 1, 2, 3).

In general, all management practices to optimize the root environment can only indirectly influence crop growth and yield through their direct effect on the root systems with limits dictated by the species genetics [31]. Muskmelon and tomato plant roots are especially vulnerable to Hypoxia stress $\mathrm{O}_{2}$ deficiency in the soil reduces adenosine triphosphate (ATP) production leading to lower uptake and transport of nutrients to the shoot leading to a reduction in leaf growth and photosynthesis [32]. The results of this study on muskmelon add new information to the findings of Bhattarai et al. [18, 3335] and Sharma et al. [36] that show positive effects of soil aeration on growth and yield of other crops.

\section{Conclusions}

The results of this experiment show that it is feasible to configure installation and operation of commerciallyavailable, permanent or semi-permanent, sub-surface drip irrigation systems to manipulate the root environment and indirectly influence growth and yield of greenhouse-produced muskmelon and tomato. For muskmelon experiment, deeper drip tubing placement permits a wider range of mechanical cultivation practices but can induce $\mathrm{O}_{2}$ deficits in the wetted zone around the emitters especially for low-frequency, highvolume irrigation applications. The Total DM of muskmelon at 75 DAT increased with increasing tubing placement depth and aeration frequency, the $D_{40}$ was increased the Total DM by $39.3 \%$ compared with the $\mathrm{D}_{10}$, and the $\mathrm{A}_{1}$ was increased the Total DM by $46.9 \%$ compared with the $A_{N}$. The fruit yield of muskmelon and tomato increased with increasing aeration frequency, and 1-d aeration intervals was increased the yield of muskmelon by $21.5 \%$ compared with the control, and the $\mathrm{D}_{15} \mathrm{~A}_{2}$ was increased the tomato yield by $27.8 \%$ compared with the $\mathrm{D}_{10} \mathrm{~A}_{\mathrm{N}}$. Our results demonstrated that the negative impact of any such deficit on the measured responses can be offset by soil aeration via the drip tubing.

\section{Methods}

\section{Experimental conditions, setup, and treatments}

The muskmelon experiment was conducted in a $108 \mathrm{~m}$ long and $8 \mathrm{~m}$ wide greenhouse located in Yangling, Shaanxi Province, Northwest China $\left(34^{\circ} 17^{\prime} \mathrm{N}\right.$ latitude, $108^{\circ} 02^{\prime} \mathrm{E}$ longitude) from April 24 to July 12, 2014. Tomato experiment was conducted from Oct 182,014 to May 20, 2015 in the same greenhouse. The climate is semi-arid with a long-term average annual precipitation of $550-650 \mathrm{~mm}$, with the average annual sunshine of $2163.8 \mathrm{~h}$ and 210 frost-free days. The soil texture of root growth area was clay loam with $25.4 \%$ sand, $44.1 \%$ silt, and $30.5 \%$ clay. $\mathrm{pH}$ was 7.82 , dry bulk density $1.35 \mathrm{~g}$ $\mathrm{cm}^{-3}$, porosity $49.4 \%$, and gravimetric field capacity $28.2 \%$ (volumetric field capacity $38 \%$ ). The physical and chemical characteristics of the irrigation water: $\mathrm{pH}$ was 7.90, EC was $2.71 \mathrm{ds} \mathrm{m}^{-1}$, total suspended solids were $15 \mathrm{mg} \mathrm{L}^{-1}$, COD $\mathrm{Mn}$ was $1.2 \mathrm{mg} \mathrm{L}^{-1}$.

The main drip irrigation tube was connected to an air pump, both water and air were supplied to the soil through the tube (Fig. 7). Drip irrigation tubes ( $\$ 16$ subsurface drip irrigation pipe, Qinchuan water-saving irrigation equipment engineering Co. Ltd., Yangling, China), $16 \mathrm{~mm}$ diameter with emitter spacing of $0.30 \mathrm{~m}$, were buried to the appropriate depth spaced $0.50 \mathrm{~m}$ apart along the ridges. The subsurface drip irrigation tubes had a peculiar labyrinth channel structure, so it can promote the uniformity discharge rate of air/water as much as possible. The drip irrigation tubes were connected to a distribution system designed to supply both water and air. Each plot had 35 to 36 emitters.

Muskmelon cultivar Shantian No.1 (Northwest New Horizon Facilities Agriculture Development Co. Ltd., Yangling Shaanxi, China) is one of over 100 cultivars of the Chinese 'Hami' reticulated melon group (Cucumis melo L.). It is an early maturing, monoecious cultivar with separate male and female flowers on the same plant. Each plant produces 4-5 small (300-350 g), fragrant, sweet, crisp-fleshed, fruits that are very popular with consumers. The tested cultivar of tomato (Lycopersicon esculentum Mill.) was Fen-Yu-Yang-Gang (Northwest New Horizon Facilities Agriculture Development Co. Ltd., Yangling Shaanxi, China).

Before transplanting, the soil was rototilled, and $120 \mathrm{t} / \mathrm{ha}$ of decomposed organic manure (pig and sheep manure), $400 \mathrm{~kg} / \mathrm{ha}$ of compound fertilizer (18\% $\mathrm{N}, 15 \% \mathrm{P}_{2} \mathrm{O}_{5}$, and $12 \% \mathrm{~K}_{2} \mathrm{O}$ ), and $1500 \mathrm{~kg} / \mathrm{ha}$ of diammonium phosphate $\left(18 \% \mathrm{~N}\right.$ and $\left.46 \% \mathrm{P}_{2} \mathrm{O}_{\mathrm{e}}\right)$ were broadcast uniformly in the soil as the basal fertilizer. After 20 days, 26 plugs of muskmelon (or tomato) were transplanted to the experimental plots spaced $0.40 \mathrm{~m}$ apart within 2 rows spaced $0.5 \mathrm{~m}$ apart on the ridges. To prevent the lateral spread of air and water into adjacent treatments, the plots were separated from each other by a $1.5 \mathrm{~m}$ wide empty space. Posttransplanting management practices (i.e. fertilization, agricultural chemicals spraying, fruit pruning etc.) for all plots were consistent with local production practice. Fruiting was not restricted, although some farmers prune the flowers.

Based on the balance between soil air update rate and labor cost, artificial aeration treatments of tomato were 


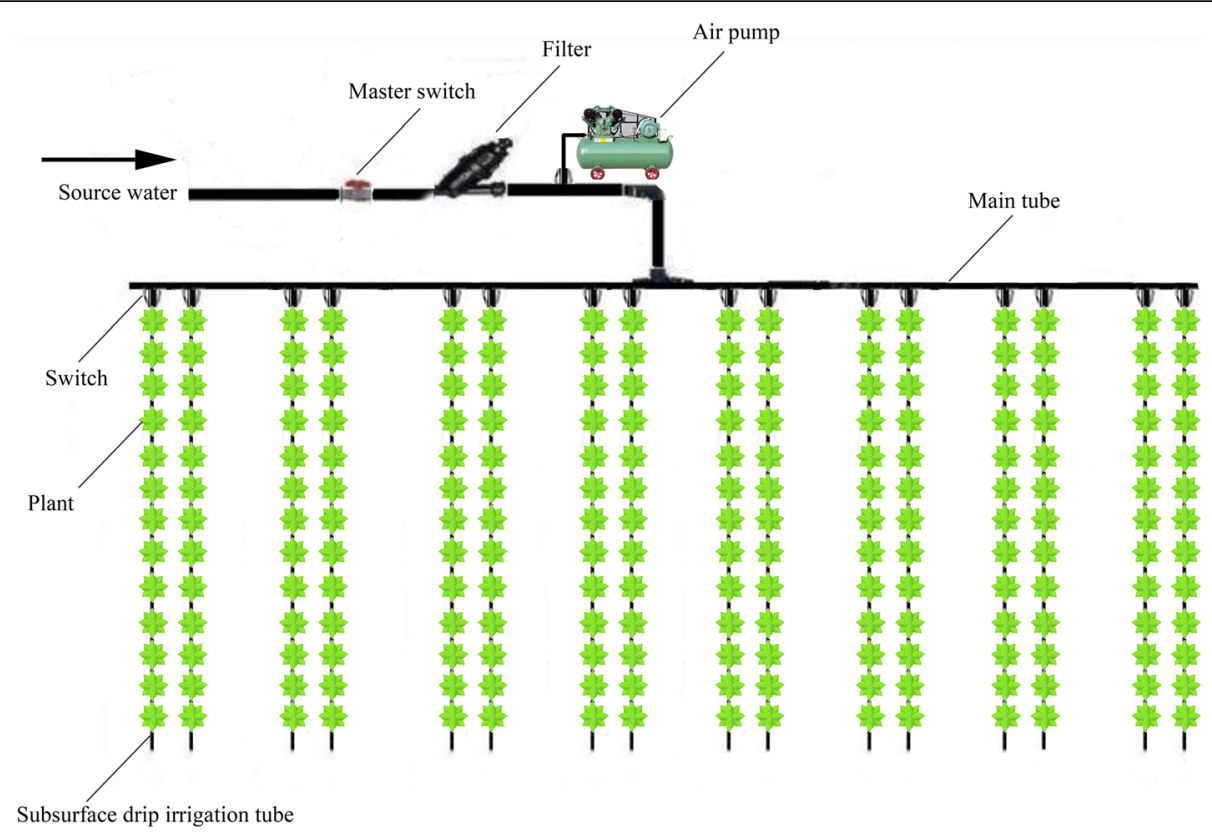

Fig. 7 experimental arrangement of an example block

none or aeration at 2-day, and 4-day intervals, and interval of aeration for muskmelon were none or aeration at daily, 2-day, and 4-day intervals beginning the first day after transplanting and designated as $A_{\text {interval in day (i.e. }}$ $A_{1}, A_{2}, A_{4}$, and $A_{N}$ ). For each treatment, $405 \mathrm{~L}$ of air was applied to each plot via the drip tubing using a manifold connected to an air compressor. The flow rate for each plot was about $10.2 \mathrm{~L} \mathrm{~min}^{-1}$. The air which injected via subsurface drip irrigation tubes have a characteristic of high $\mathrm{O}_{2}$ concentration and low $\mathrm{CO}_{2}$ concentration compared with air which originally stored in soil pore space. The injected air/oxygen consumed by soil microorganisms, soil animals, crop roots. Moreover, a fraction of oxygen diffuses to the atmosphere because of the chimney effect. This volume was calculated as [5, 37]:

$$
\mathrm{V}_{\mathrm{A}}=\left[S L\left(1-\rho_{\mathrm{b}} / \rho_{s}\right)\right] / 1000 \eta .
$$

where $V_{A}$ was the amount of air injected, $S$ the area of a cross-section between rows, $L$ the length of plot, $\rho_{\mathrm{b}}$ the soil bulk density, and $\rho_{s}$ the soil particle density. $\eta$ an application efficiency coefficient for aeration system.

Irrigation timing and amount demand of tomato experiment is mainly driven by farmers' perceptions and climatic conditions. For the muskmelon experiment, following recommended production practices the plots were surface-irrigated at the time of transplanting. Soil water content was measured and controlled using a Field TDR 200 soil moisture meter (Spectrum, Aurora, IL,
USA). A 60-cm deep probe was installed in the center of each plot. Soil water content was measured at $10-\mathrm{cm}$ intervals down to a depth of $60 \mathrm{~cm}$. The gravimetric water content $\left(\theta_{\mathrm{g}}\right)$ averaged over the $0-60 \mathrm{~cm}$ at the time of transplanting was measured. Subsurface drip irrigation treatments were based on the measured gravimetric water content averaged over the $0-60 \mathrm{~cm}$ depth of the soil profile on these dates. The location of soil sampling was between two rows of muskmelon (or tomato), each soil sampling with three replicates. Muskmelon treatments, designated as $\mathrm{I}_{\text {to } \% \text { field capacity }}$ (i.e. $\mathrm{I}_{70}, \mathrm{I}_{80}$, and $\left.I_{90}\right)$, were based on replenishing the water in the soil volume $\left(\mathrm{V}_{\mathrm{s}}\right)$ in $60 \mathrm{~cm}$ of the soil profile to 70,80 , and $90 \%$ of the gravimetric field capacity. The irrigation treatment amount in litre of muskmelon were calculated as: $[5,38]$

$$
V_{I}=V_{s} \times \rho b \times\left(\theta_{g f c} \times q_{1}-q_{2}\right) /(\eta \times 1000) .
$$

Where $V_{I}$ was the irrigation amount, $\rho_{b}$ the soil bulk density, $\theta_{g f c}$ field capacity, $\mathrm{q}_{1}$ the irrigation level $(0.7,0.8$, or 0.9$), \mathrm{q}_{2}$ the measured soil moisture content, and $\eta$ an application efficiency coefficient for irrigation system. Irrigation timing demand is mainly driven by farmers' perceptions and climatic conditions. Details of irrigation timing and amounts during muskmelon growth periods are shown in Table 2. Pre-irrigation soil moisture of muskmelon for different treatments and soil depth at 22 and 59 DAT are shown in Fig. 8. 
Table 2 Details of irrigation timing and amounts during muskmelon growth period

\begin{tabular}{|c|c|c|c|c|}
\hline \multirow[t]{2}{*}{ Combination } & \multicolumn{3}{|c|}{ Irrigation timing } & \multirow[t]{2}{*}{ Total Irrigation amount (mm) } \\
\hline & ODAT (mm) & 23DAT $(\mathrm{mm})$ & 60DAT (mm) & \\
\hline$D_{10} A_{N} I_{70}$ & 70 & 29.98 & 53.28 & 153.26 \\
\hline$D_{10} A_{1} I_{80}$ & 70 & 62.21 & 70.88 & 203.08 \\
\hline$D_{10} A_{2} I_{90}$ & 70 & 84.87 & 94.29 & 249.16 \\
\hline$D_{10} A_{4} I_{70}$ & 70 & 47.36 & 59.07 & 176.43 \\
\hline$D_{25} A_{N} I_{80}$ & 70 & 57.33 & 58.47 & 185.80 \\
\hline$D_{25} A_{1} I_{90}$ & 70 & 88.39 & 77.01 & 235.41 \\
\hline$D_{25} A_{2} I_{70}$ & 70 & 49.95 & 37.82 & 157.77 \\
\hline$D_{25} A_{4} I_{80}$ & 70 & 64.03 & 63.11 & 197.14 \\
\hline$D_{40} A_{N} l_{90}$ & 70 & 82.75 & 83.00 & 235.75 \\
\hline$D_{40} A_{1} I_{70}$ & 70 & 44.20 & 27.65 & 141.86 \\
\hline$D_{40} A_{2} I_{80}$ & 70 & 60.88 & 68.76 & 199.64 \\
\hline $\mathrm{D}_{40} \mathrm{~A}_{4} \mathrm{I}_{90}$ & 70 & 93.67 & 82.16 & 245.83 \\
\hline
\end{tabular}

$D A T$ days after transplanting

\section{Experimental design}

\section{Muskmelon experimental design}

A full $4^{1} \times 3^{2}$ factorial of the 36 experimental treatment combinations and would require 108 plots for 3 replicates (Table 3). As with all fractional factorial designs, some effects are not estimable and confounding of lower and higher order effects is unavoidable. In this case, the three-factor interaction effect was not estimable. The main effects are independently estimable and it was possible to determine the existence of two-factor interactions. Even with these limitations, the design provided good stability and permitted estimation of the effects of primary interest comparable to the output of the much more expensive complete factorial experiment requiring 108 experimental plots.

\section{Tomato experimental design}

The experiment was limited to 6 treatments arranged as a randomised complete block design with drip irrigation tube burial depth and aeration frequency (Table 4).

\section{Plant measurements}

At 75 days after transplanting (DAT), all marketable fruits of muskmelon were harvested from each plot. And 214 days after transplanting (DAT), all marketable fruits of tomato ( 3 trusses) were harvested from each plot. The fruits were weighed and the fresh fruit weight per plant calculated. At 25, 55, and 75 DAT leaf area index (LAI) was measured by using AccuPARLP-80 canopy analyzer (Decagon Devices, Pullman, Washington 99,163, USA)

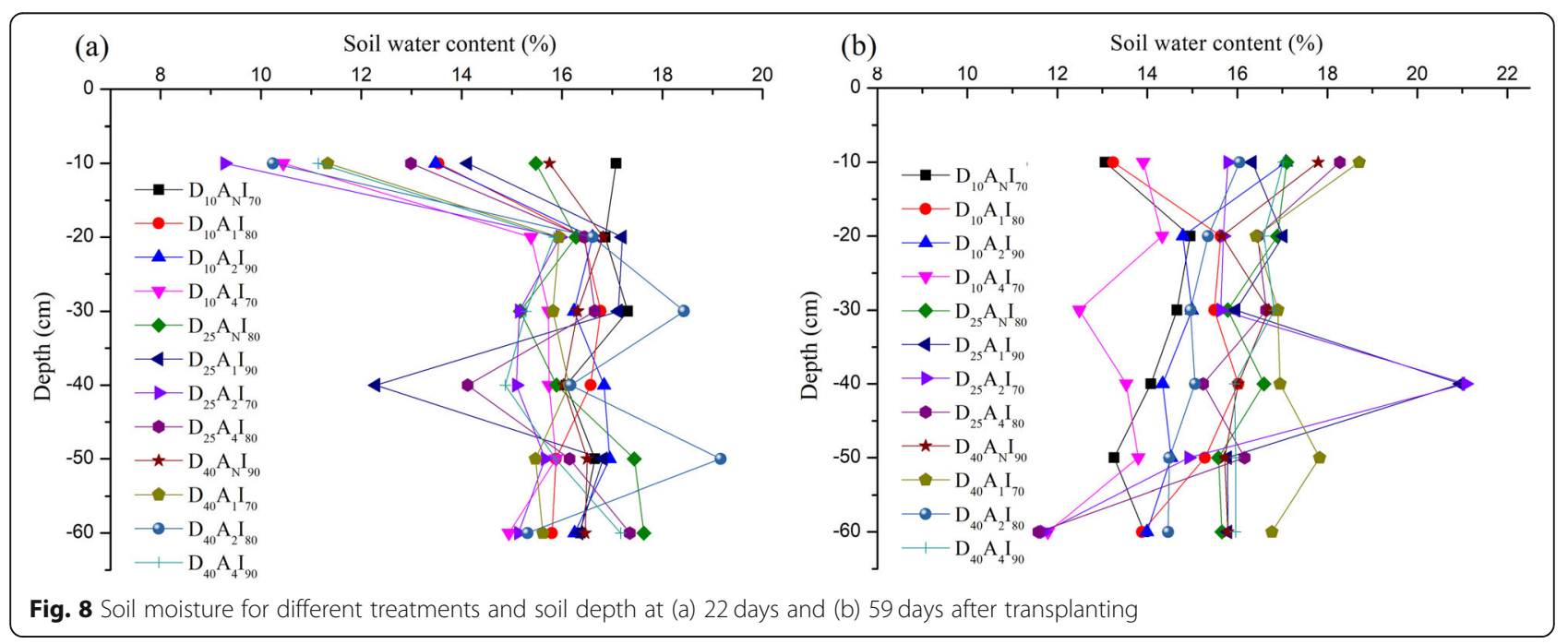


Table 3 Muskmelon experimental design

\begin{tabular}{|c|c|c|c|c|c|c|c|c|c|c|c|c|}
\hline Combination & 1 & 2 & 3 & 4 & 5 & 6 & 7 & 8 & 9 & 10 & 11 & 12 \\
\hline Depth (D) & $D_{10}$ & $D_{10}$ & $D_{10}$ & $D_{10}$ & $D_{25}$ & $D_{25}$ & $D_{25}$ & $D_{25}$ & $D_{40}$ & $D_{40}$ & $D_{40}$ & $D_{40}$ \\
\hline Aeration (A) & $A_{N}$ & $A_{1}$ & $\mathrm{~A}_{2}$ & $\mathrm{~A}_{4}$ & $A_{N}$ & $A_{1}$ & $\mathrm{~A}_{2}$ & $\mathrm{~A}_{4}$ & $A_{N}$ & $A_{1}$ & $\mathrm{~A}_{2}$ & $\mathrm{~A}_{4}$ \\
\hline Irrigation (I) & $I_{70}$ & $\mathrm{I}_{80}$ & $I_{90}$ & $I_{70}$ & $\mathrm{I}_{80}$ & $\mathrm{I}_{90}$ & $I_{70}$ & $I_{80}$ & $I_{90}$ & $I_{70}$ & $1_{80}$ & $I_{90}$ \\
\hline
\end{tabular}

$D_{10}$, subsurface tubing placement depth at $10 \mathrm{~cm} ; D_{25}$, subsurface tubing placement depth at $25 \mathrm{~cm} ; D_{40}$, subsurface tubing placement depth at $40 \mathrm{~cm}$; $A_{N}$, aeration treatments were none; $A_{1}$, aeration at daily; $A_{2}$, aeration at 2-day; $A_{4}$, aeration at 4 -day; $I_{70}$ irrigation to $70 \%$ of the gravimetric field capacity; $I_{80}$ irrigation to $80 \%$ of the gravimetric field capacity; $I_{90}$ irrigation to $90 \%$ of the gravimetric field capacity

based on solar radiation transmittance. After harvesting, the remaining above-ground portion of all plants in each experimental plot were collected. The roots were removed and washed through a sieve. Stem and leaves and root were oven dried at $60^{\circ} \mathrm{C}$ for $48 \mathrm{~h}$ according to Shao et al., 2008; Ahmadi et al., 2014; Ramírez et al., 2014 [39-41]. Root dry weight was then measured on 3 muskmelon (tomato) plants from each plot.

\section{Data analyses and statistics}

The experimental data were organized in Microsoft Excel 2016. The statistical analyses were performed with the SPSS 22 software package (IBM, Armonk, New York). All figures were constructed using the graphing software OriginPro 9.0 (Origin Lab Corporation, One Roundhouse Plaza, Suite 303, Northampton, MA 01060, USA).

\section{Muskmelon data}

Data are expressed as the mean. Three replicates were used for each experimental determination. Data were analyzed using a residual test method before statistical analysis, and the data met the assumption of homogeneity of variances and followed normal distribution. Mean differences between treatments were assessed by analysis of variance (ANOVA). Post-hoc pairwise comparisons of the treatment means were performed using Duncan's multiple range test. Differences were considered significant at the level of 0.05 . The main purpose of the ANOVA was to assess the main effects and the 2-way interactions between drip irrigation tube burial depth, irrigation level and artificial aeration frequency on tomato yield, LAI, post-harvest dry matter partitioning, and irrigation use efficiency. The significances were defined at the level of 0.05 and 0.01 .

Table 4 Tomato experimental design

\begin{tabular}{lllllll}
\hline Combination & 1 & 2 & 3 & 4 & 5 & 6 \\
\hline Depth (D) & $D_{15}$ & $D_{15}$ & $D_{15}$ & $D_{40}$ & $D_{40}$ & $D_{40}$ \\
Aeration (A) & $A_{N}$ & $A_{2}$ & $A_{4}$ & $A_{N}$ & $A_{2}$ & $A_{4}$ \\
\hline
\end{tabular}

$\mathrm{D}_{15}$, subsurface tubing placement depth at $15 \mathrm{~cm} ; \mathrm{D}_{40}$, subsurface tubing placement depth at $40 \mathrm{~cm} ; A_{N}$, aeration treatments were none; $A_{2}$, aeration at 2-day; $A_{4}$, aeration at 4-day

\section{Tomato data}

The experimental design was taken as a $2 \times 3$ factorial with 3 replicates. Data were analyzed using a residual test method before statistical analysis, and the data met the assumption of homogeneity of variances and followed normal distribution, and all treatment means were compared for significant differences using the Duncan's new multiple-range test at level of $P=0.05$.

\section{Abbreviations}

EC: Electrical conductivity; DAT: Days after transplanting; LAl: Leaf area index; DM: Dry matter; $D_{c m}$ (i.e. $D_{10}, D_{25}$, and $D_{40}$ ): Irrigation tubing placement depths were 10,25 , and $40 \mathrm{~cm}$ below the surface of the ridge; $I U E_{f}$ or IUE $E_{d m}$ : Irrigation use efficiency as (marketable fresh fruit yield per plant) or as (g total DM per plant) divided by (liter total irrigation water applied); $A_{\text {interval }}$ in day (i.e. $A_{1}, A_{2}, A_{4}$, and $A_{N}$ ): Interval of aeration for muskmelon/tomato were none or aeration at daily, 2-day, and 4-day intervals beginning the first day after transplanting; $I_{\text {to\% }}$ field capacity (i.e. $I_{70}, I_{80}$, and $I_{90}$ ): Muskmelon treatments, designated as, were based on replenishing the water in the soil volume $\left(V_{s}\right)$ in $60 \mathrm{~cm}$ of the soil profile $\left(V_{s}=5.5 \mathrm{~m}^{2} \times 0.6 \mathrm{~m}\right)$ to 70,80 , and $90 \%$ of the gravimetric field capacity; $L A I_{\text {days }}$ (i.e. $\mathrm{LAl}_{25}, \mathrm{LAl}_{55}$, and $\mathrm{LAl}_{75}$ ): $\mathrm{LAl}$ of muskmelon plants measured by canopy solar radiation transmittance at 25 , 55 , and 75 days after transplanting.

\section{Acknowledgements}

We acknowledge the support of Jian Xu, Jun Gu and Yahui Guan (Institute of Soil and Water Conservation, Northwest A\&F University) for their assistance in the field and laboratory work.

\section{Authors' contributions}

Conceived and designed the experiments: LY and NWQ. Performed the experiments: LY and ZMZ. Analyzed the data: LY and WJW. Contributed reagents/materials/analysis tools: LY CXS WJW ZMZ ZZX. Wrote the paper: LY. Revised the manuscript: LY, NWQ, CXS and ZZX. All authors have read and approved the manuscript.

\section{Funding}

This work is supported jointly by the National Key Research Project of China "13th Five Year Plan" (No. 2016YFC0400202), Natural Science Foundation of China (No. 41807041; No. 41831284; No. 51679205), Natural Science Foundation of Guangdong Province (No. 2018A0303130149), Science and Technology Program of Guangzhou (No.20181002SF0530), Science and Technology Program of Xi 'an (No. 20193052YF040NS040), Fundamental Research Funds for the Central Universities (GK201903115; 2412018JC002), and the Program of Introducing Talents of Discipline to Universities (B16011). The Funding bodies were not involved in the design of the study and collection, analysis, and interpretation of data and in writing the manuscript.

Availability of data and materials

The datasets used and/or analyzed during the current study are available from the corresponding author on reasonable request.

Ethics approval and consent to participate Not applicable. 


\section{Consent for publication}

Not applicable.

\section{Competing interests}

The authors declare that they have no competing interests.

\section{Author details}

'Northwest Land and Resources Research Center, Shaanxi Normal University, Xi'an 710119, Shaanxi, China. Institute of Soil and Water Conservation, Northwest A\&F University, Yangling 712100, Shaanxi, China. ${ }^{3}$ Institute of Water-saving Agriculture in Arid Areas of China (IWSA), Northwest A\&F University, Yangling 712100, Shaanxi, China. ${ }^{4}$ Institute of Soil and Water Conservation, Chinese Academy of Sciences \& Ministry of Water Resources, No.26 Xinong Road, Yangling 712100, Shaanxi, China. ${ }^{5}$ College of Water Resources and Hydropower, State Key Laboratory Base of Eco-Hydraulic Engineering in Arid Area, Xi 'an University of Technology, Xi'an 710048, China. ${ }^{6}$ Henan Provincial Water Conservancy Research Institute, Zhengzhou 450000, China. ${ }^{7}$ College of Resources and Environment, Shanxi University of Finance and Economics, Taiyuan 030006, Shanxi, China. ${ }^{8}$ Key Laboratory of Vegetation Ecology, Ministry of Education, Institute of Grassland Science, Northeast Normal University, Changchun 130024, Jilin Province, China. ${ }^{9}$ State Environmental Protection Key Laboratory of Wetland Ecology and Vegetation Restoration, School of Environment, Northeast Normal University, Changchun 130117, Jilin Province, China.

Received: 11 October 2019 Accepted: 20 March 2020

Published online: 06 April 2020

\section{References}

1. Chang J, Wu X, Wang Y, Meyerson LA, Gu BJ, Min Y, Xue H, Peng CH, Ge Y. Does growing vegetables in plastic greenhouses enhance regional ecosystem services beyond the food supply? Front Ecol Environ. 2013;11: 43-9.

2. Jiang W, Qu D, Mu D, Wang L. Protected cultivation of horticultural crops in China, In Horticultural Reviews, Volume 30 (ed J. Janick). John Wiley \& Sons. Oxford, UK: Inc; 2003. Chapter 4.

3. Wittwer $\mathrm{SH}$, Castilla N. Protective cultivation of horticultural crops worldwide. Hort Tech. 1995;5:6-23.

4. Mostaghami S, Mitchell KJ, Lembke WD. Effect of discharge rate on distribution of moisture in heavy soils irrigated from a trickle source. Trans ASAE. 1981;25:2081-5.

5. Li Y, Niu WQ, Xu J, Wang JW. Zhang MZ, Iv W. Root morphology of greenhouse produced muskmelon under sub-surface drip irrigation with supplemental soil aeration Sci Hortic. 2016:201:287-94.

6. Michelakis N, Vougioucalou E, Clapaki G. Water use, wetted soil volume, root distribution and yield of avocado under drip irrigation. Agr Water Manage. 1993;24:119-31.

7. Ben-Noah I, Friedman SP. Review and evaluation of root respiration and of natural and agricultural processes of soil aeration. Vadose Zone J. 2018;17: 170119.

8. Cook FJ, Thorburn PJ, Fitch P, Bristow KL. WetUp: a software tool to display approximate wetting patterns from drippers. Irrig Sci. 2003;22:129-34.

9. Smit B, Stachowiak M, Volkenburgh V. Cellular processes limiting leaf growth in plants under hypoxic root stress. J Exp Bot. 1989;40:89-94.

10. Li TL, Chen YD, Liu YL, Qin X. Effects of rhizosphere $\mathrm{CO}_{2}$ concentration on root growth and activity of netted muskmelon. Transactions of the CSAE. 2009;25:210-5.

11. Liu YL, Li TL, Sun ZP, Chen YD. Effects of Rhizosphere $\mathrm{CO}_{2}$ concentration on plant growth and root nitrogen metabolism of muskmelon. Sci Agric Sin. 2010;43:2315-24

12. Liu YL, Li TL, Sun ZP, Chen YD. Impacts of root-zone hypoxia stress on muskmelon growth, its root respiratory metabolism, and anti oxidative enzyme activities. Chin J Appl Ecol. 2010;21:1439-45.

13. Bhattarai SP, Dhungel J, Midmore DJ. Oxygation improves yield and qualityand minimizes internal fruit crack of cucurbits on a heavy clay soil in the semi-arid tropics. J Agric Sci. 2010;2:17-25.

14. Liu Y, Zhou Y, Wang T, Pan J, Zhou B, Muhammad T, Zhou C, Li Y. Micronano bubble water oxygation: synergistically improving irrigation water use efficiency, crop yield and quality. J Clean Prod. 2019;222:835-43.

15. Pendergast $L$, Bhattarai SP, Midmore DJ. Benefits of oxygation of subsurface drip-irrigation water for cotton in a vertosol. Crop Pasture Sci. 2013;64:1171-81.
16. Bhattarai SP, Huber S, Midmore DJ. Aerated subsurface irrigation water gives growth and yield benefits to zucchini, vegetable soybean and cotton in heavy clay soils. Ann Appl Biol. 2004;144:285-98.

17. Bhattarai SP, Midmore DJ. Influence of soil moisture on yield and quality of tomato on a heavy clay soil. Proc Int Symp Harnessing Potential Horticulture Asian-Pac Region. 2005:451-4.

18. Bhattarai SP, Pendergast L, Midmore DJ. Root aeration improves yield and water use efficiency of tomato in heavy clay and saline soils. Sci Hortic. 2006;108:278-88.

19. Bhattarai SP, Midmore DJ, Pendergast L. Yield, water-use efficiencies and root distribution of soybean, chickpea and pumpkin under different subsurface drip irrigation depths and oxygation treatments in vertisols. Irrig Sci. 2008;26:439-50

20. Zhu LF, Yu SM, Jin QY. Effects of aerated irrigation on leaf senescence at late growth stage and grain yield of rice. Rice Sci. 2012;19:44-8.

21. Murchie EH, Pinto M, Horton P. Agriculture and the new challenges for photosynthesis research. Tansley Rev. 2009;181:532-52.

22. Rieu M, Sposito G. Fractal fragmentation, soil porosity, and soil water properties: I. Theory Soil Sci Soc Am J. 1991:55:1231-8.

23. Biemelt $\mathrm{S}$, Keetman U, Albrecht $\mathrm{G}$. Re-aeration following hypoxia or anoxia leads to activation of the antioxidative defense system in roots of wheat seedlings1. Plant Physiol. 1998;116:651-8.

24. Drew MC. Oxygen deficiency and root metabolism: injury and acclimation under hypoxia and anoxia. Annu. Rev. plant. Physiol. Plant Mol. Biol. 1997;48: 223-50.

25. Munns R, Sharp RE. Involvement of abscisic acid in controlling plant growth in soils of low water potential. Aust J Plant Physiol. 1993;20:425-37.

26. Chen XM, Dhungel J, Bhattarai SP, Torabi M, Pendergast L, Midmore DJ. Impact of oxygation on soil respiration, yield and water use efficiency of three crop species. J Plant Ecol. 2011:4:236-48.

27. Bonachela S, Quesada J, Acuna RA, Magan JJ, Marfa O. Oxyfertigation of a greenhouse tomato crop grown on rockwool slabs and irrigated with treated wastewater: oxygen content dynamics and crop response. Agric Water Manag. 2010:97:433-8.

28. Ityel E, Ben-Gal A, Silberbush M, Lazarovitch N. Increased root zone oxygen by a capillary barrier is benefcial to bell pepper irrigated with brackish water in an arid region. Agric Water Manag. 2014;131:108-14.

29. Shahien MM, Abuarab ME, Magdy E. Root aeration improves yield and water use efficiency of irrigated potato in sandy clay loam soil. Int J Adv Res. 2014:2(10):310-20.

30. Li Y, Niu WQ, Wang JW, Liu L, Zhang MZ. Effects of artificial soil aeration volume and frequency on soil enzyme activity and microbial abundance when cultivating greenhouse tomatoes. Soil Sci Soc Am J. 2016;80:1208-21.

31. Boyer JS. Plant productivity and environment. Science. 1982;218:443-8.

32. Barrett-Lennard EG. The interaction between waterlogging and salinity in higher plants: causes, consequences and implications. Plant Soil. 2003;253:35-54.

33. Bhattarai SP, Midmore DJ. Oxygation enhances growth, gas exchange and salt tolerance of vegetable soybean and cotton in a saline Vertisol. J Integr Plant Biol. 2009;51:675-88

34. Bhattarai SP, Su N, Midmore DJ. Oxygation unlocks yield potentials of crops in oxygen-limited soil environments. Adv Agron. 2005;88:313-77.

35. Bhattarai SP, Salvaudon C, Midmore DJ. Oxygation of the Rockwool substrate for hydroponics. Aquaponics Journal. 2008:49:29-33.

36. Sharma SP, Leskovar DI, Crosby KM, Volder A, Ibrahim AMH. Root growth, yield, and fruit quality responses of reticulatus and inodorus melons (Cucumis melo L.) to deficit subsurface drip irrigation. Agr Water Manage. 2014;136:75-85.

37. Niu WQ, Fan WT, Persaud N, Zhou XB. Effect of post-irrigation aeration on growth and quality of greenhouse cucumber. Pedosphere. 2013;23:790-8.

38. Pei Y, Bie ZL. Efects of diferent irrigation minima on the growth and physiologica1 characteristics of lettuce under plastic greenhouse. Trans CSAE. 2008:24:207-11

39. Shao G, Zhang Z, Liu N, Yu S, Xing W. Comparative effects of deficit irrigation (DI) and partial rootzone drying (PRD) on soil water distribution, water use, growth and yield in greenhouse grown hot pepper. Sci Hortic. 2008;119:11-6.

40. Ahmadi SH, Agharezaee M, Kamgar-Haghighi AA, Sepaskhah AR. Effects of dynamic and static deficit and partial root zone drying irrigation strategies on yield, tuber sizes distribution, and water productivity of two field grown potato cultivars. Agric Water Manag. 2014;134:126-36. 
41. Ramírez DA, Yactayo W, Gutiérrez R, Mares V, De Mendiburu F, Posadas A, Quiroz R. Chlorophyll concentration in leaves is an indicator of potato tuber yield in water-shortage conditions. Sci Hortic. 2014;168:202-9.

\section{Publisher's Note}

Springer Nature remains neutral with regard to jurisdictional claims in published maps and institutional affiliations.

Ready to submit your research? Choose BMC and benefit from:

- fast, convenient online submission

- thorough peer review by experienced researchers in your field

- rapid publication on acceptance

- support for research data, including large and complex data types

- gold Open Access which fosters wider collaboration and increased citations

- maximum visibility for your research: over $100 \mathrm{M}$ website views per year

At BMC, research is always in progress. 